Open Access

\title{
Friend or foe? The various responses of the Indonesian state to sustainable non-state palm oil initiatives
}

\author{
Eusebius Pantja Pramudya* (D, Otto Hospes and C. J. A. M. Termeer
}

\author{
* Correspondence: \\ eusebius.pramudya@wur.nl \\ Wageningen University and \\ Research, Wageningen, Netherlands
}

\section{Introduction}

In 2003, market leaders in palm oil consuming countries were approached by environmental non-government organisations (NGOs) to develop the Roundtable on Sustainable Palm Oil (RSPO) in addressing social and environment impacts of the global palm oil production as highlighted in an intensive NGO campaign (Khor 2011; Paoli et al. 2010). Cooperation among market leaders is possible among those who control the market, according to Mügge (2006). The RSPO as 'roundtable governance' combines moral and market authorities to change the behaviour of companies and government regulations without the direct involvement of the nation state. As a form of 'private governance', the RSPO provides alternative instruments in addressing concerns surrounding the social and environmental impacts of business (Pesqueira and Glasbergen 2013; Schouten et al., 2012; Andonova 2010; von Geibler 2013).

The emergence of private governance, in itself, gives rise to the role of the state in four areas: mandating (defining minimum standards for business performance embedded within the legal framework), facilitating (developing enabling conditions or providing incentives), partnership (bringing complementary skills and inputs), and endorsing (giving political support) (Fox et al., 2002). Gulbrandsen (2014) argues that the state might be highly involved in the agenda-setting and negotiation, but then decreases its involvement in the implementation and evaluation. Other scholars found that the state might also develop roles by cooperating at a trans-governmental level, by developing new institutions based on practices and rules introduced by the private governance, or by competing for ruling authority (Lawrence et al., 2012; Smith and Fischlein 2010; von Geibler 2013). However, business has the concern that increasing a state's regulatory activity inevitably raises public expenditure and potentially diverts investment (Detomasi 2007).

In spite of the different roles, the general image is that nation states in the Third World are reluctant to promote environmental and social changes while such private governance models directly impact domestic economic development (Giessen et al. 2016; Abbott 2012; Mol 2010). However, nation states cannot simply ignore these private governance arrangements, as private actors have become one among equals with the state, and nation states are increasingly dependent on trade in achieving their

(c) The Author(s). 2018 Open Access This article is distributed under the terms of the Creative Commons Attribution 4.0 International License (http://creativecommons.org/licenses/by/4.0/), which permits unrestricted use, distribution, and reproduction in any medium, provided you give appropriate credit to the original author(s) and the source, provide a link to the Creative Commons license, and indicate if changes were made. 
development objectives (Cutler 1999; Milker 2011; Jessop 1997; Cashore 2002; Menocal 2004; Evans 1997).

In Indonesia, as the biggest palm oil producing country, we would expect the state's enormous support to oil palm producers. In addition, in the prevalence of increasing nationalism we would expect a more consistent rejection of interference from private governance, due to its being perceived as interference. However, this is not the case for Indonesia. After an uncomfortable interaction with RSPO, the Indonesian state developed a national-based standard with the Indonesian Sustainable Palm Oil (ISPO) in 2009, which is often seen as a rival to RSPO. The emergence of ISPO does not cease interaction between RSPO and the Indonesian state. Later, the Indonesian state exhibited contrasting responses to the emergence of two non-state sustainable palm oil initiatives in 2015: the Indonesia Palm Oil Pledge (IPOP) and the Indonesian Palm Oil Platform (InPOP). The Indonesian state confronted IPOP, which was established by leading palm oil companies and facilitated by the Indonesian Chamber of Trade and Industry (KADIN). This lead to IPOP's disbandment in June 2016. Contrarily, the Indonesian state responded positively and collaborated well with InPOP, despite presenting similar objectives, program components and stakeholders. The Indonesian state, thus, has had varied responses to the emergence of non-state initiated palm oil sustainability governance arrangements.

The lack of consistency of the Indonesian state in responding to the non-state sustainable palm oil initiatives might affect business in several ways. Simply ignoring the issue of sustainable palm oil is not possible due the increasing awareness of the global market reflected in the increasing sales of certified sustainable palm oil, standard compliant producers and commitments made by nation states (RSPO 2017; Potts et al. 2014). Improving sustainability practices in an individual company alone might not be sufficient owing to complexities in implementing regulation, understanding consumption, and global palm oil supply networks involving multiple scales, locations and actors (D'Antone and Spencer 2015; Azhar et al. 2017; Oosterveer 2015). Conflicting with the state, without any doubts, would severely impact companies particularly with the threat for banning and penalties. The lack of consistency apparent in the Indonesian state's approach indeed confuses business on what extent they could participate in the nonstate sustainable palm oil initiatives.

The objective of this paper is to explain why the Indonesian state has reacted differently to non-state sustainable palm oil governance initiatives and to draw lessons for business. In achieving this objective, we have two questions. First, how has the Indonesian state responded differently to the emergence of non-state sustainable palm oil initiatives and what are the underlying mechanisms of these responses?. Second, how can business prevent unexpected, if not outright hostile, reactions from the state towards non-state governance initiatives in sustainable palm oil?

The analysis uses the Transnational Business Governance Interaction Framework (TBGIF), which is developed by Eberlein et al. (2014) to analyse interactions. Interactions are defined as 'the myriad of ways in which governance actors and institutions engage with and react to one another' (Eberlein et al., 2014, 2). Focusing on interactions enables a deeper understanding than observing responses as a one-shot static occurrence. It allows for an analysis of the dynamic interplay between acts, reactions and interactions (Weick 1987), and thus involves initial responses, engagements, reactions, and follow-up activities. 
This article is organised in seven sections. The second section following this introduction discusses the conceptual framework. The section presenting methodology follows. The fourth section describes the cases of the Indonesian state's responses to RSPO, IPOP and InPOP. The fifth section presents the analysis of the case using TBGIF, followed by discussion about interaction and business implications. The conclusion summarises the arguments of the paper.

\section{Conceptual framework: Business, sustainability governance initiatives and the governance interaction}

In the past, initiatives for sustainability centred in the state and its coercive mechanism, which together the nation states developed intergovernmental initiatives (Abbott 2012; Perez-batres et al., 2011). The state-centric approach is under challenge with state failure, where the state alone failed to provide well-performing public services, while interstate mechanisms were constrained by long negotiation and compromises leading to the development of narrow agendas (Khan 2004; Abbott 2012, 553).

The awareness of these limitations has promoted a shift from hierarchical forms of government towards governance. Governance enables business to develop selfregulation. Although much self-regulation by business focuses on lowering transaction costs, Vogel (2010) observed that they evolve faster, covering issues that have not been addressed by government regulations. Furthermore, such self-regulation has required companies to make expenditure and undertake commitments addressing political and social pressures on business.

Some self-regulation mechanisms evolved further by involving stakeholders outside business, including NGOs (Vogel 2010, 70). These stakeholders can impose norms, values or cultures to create social order, as long as actors comply with their roles. Actions that enable business to create larger impacts include establishing and developing sustainability initiatives for leveraging standards, coordinating policy dialogue, and conducting joint action, which enable to create bigger impacts (Nelson 2017; Perez-batres et al., 2011, 846). However, their interactions are less formalized and demanding, which enable them to reach across different levels and sectors (Kooiman 2005; Termeer 2009; Abbott 2012, 547).

In cases where public agencies are involved, there is an increase in the legitimacy of business to co-govern and develop more formal relationships with a broader political system (Abbott 2012, 548; Schouten and Glasbergen 2011). Among these public agencies, the state still has prominent roles to address issues such as regulation, enforcement, or inclusion of small scale producers (Vogel 2010; Auld and Gulbrandsen 2015; Amengual and Chirot 2016). Although governing is the primary role of the state, state officials face barriers in implementing the more horizontal governance initiatives. These barriers come from conflicting convictions concerning good policy making, stereotyping potential partners, the pressure of framing the issue as a serious crisis or near to deadline, fear of undermining existing policy or not reaching governmental targets, and blocking learning by not expressing doubts, hiding internal struggles or not being willing to face disappointments (Termeer 2009, 311-13).

Although the interaction between business and public agencies, most notably the state, involves rich dynamics, the field of interaction has lacked scholarly attention. Governance studies tend to focus more on analysing individual governance arrangements (Andonova et al., 2009; C. A. Brandi 2017; Abbott and Snidal 2008). Eberlein 
et al. (2014, p. 6-14) developed the Transnational Business Governance Interaction Framework (TBGIF) to provide a conceptual framework in analysing dynamic interactions between regulatory governance arrangements. To analyse dynamics, TBGIF distinguishes various regulatory governance components or phases; these include agenda setting, rule formation, implementation, monitoring, enforcement and evaluation (Eberlein et al., 2014, p.6). Additionally, TBGIF covers several dimensions, institutions and actors, driving forces, impacts, characteristics, and changes over time.

We use TBGIF in three ways. First, we characterise interactions between the state and the private governance arrangements in four possible ways: competition, coordination, co-optation, and chaos (Eberlein, et al., 2014, p. 11-12). Competition occurs when the state imposes its conditions on private governance in order to improve its reputation, legitimacy, and authority. Coordination emerges when both the state and private governance realise that cooperation could increase the legitimacy and relevance of the state's policies. Co-optation happens when either the state or private governance has hegemony and develops meta-regulation. Chaos occurs when interactions become unpredictable and strategies become uncertain. More detailed forms of interaction are possible, such as competition through niche-carving, coordination through discursive articulation of principles, and coordination through division of labour. Some interactions can occur together, such as co-opetition and chaos, or change over time, such as chaos that transforms into competition. Some interactions are distinctive across institutional levels, such as chaos at the national level and coordination at the local level.

Second, we distinguish institutional levels of interactions: micro, meso and macro (Eberlein, et al., 2014, p. 8). At the micro level, individual actors from differing governance arrangements interact beyond what is formally required. At the meso-level, private governance schemes interact with other private governance arrangements and with state-based regulators. At the macro-level, regulatory bodies interact, creating discourse between issues; such issues can be environmental concerns and social concerns.

Third, we analyse the underlying mechanisms. The framework addresses various dimensions of interaction, such as actors, drivers, and mechanisms, as well as characteristics and changes in the interactions. These dimensions relate to institutions, events behind and around the implementation, and dynamics of the interactions. Some governance arrangements might have similar dimensions of interactions; examples of these are governance arrangements in sustainable palm oil overlapping with drivers for promoting practices in addressing the social and environmental impacts of oil palm plantation expansion.

Together, these three ways develop a comprehensive analysis of governance interaction. The interactions that have occurred among governance arrangements will be unravelled in terms of their characters, levels and underlying mechanisms.

\section{Methodology}

The research uses qualitative methodology with data collected from primary sources and secondary sources. The primary data was collected from interviews with key actors from (1) the three key ministries responsible for the development of the palm oil sector, namely the Coordinating Ministry of Economic Affairs, the Ministry of Agriculture, and the Ministry of Environment and Forestry, and (2) non-state sustainable palm oil initiatives under observation. Between early 2015 and early 2017, 15 interviews were conducted, as listed in Appendix 1. The interviews were conducted with various 
methods, that is, direct meeting, teleconference, and e-mail. The interviewees were selected using a snowball method, where certain people are selected who, because of their past or present situations, have greater accessibility and knowledge about particular events (Biernacki and Waldorf 1981). Generally, these people can develop referral chains for other possible interviewees. However, as Handcock and Gile (2011) mentioned, in snowball sampling, using either a specific group (to identify others members of the group) or individuals (to identify other individuals), we also identified other respondents by interpreting their association and presence related to the initiatives. The interpretation is related to the dynamics of natural and organic social networks, as mentioned by Noy (2008), where we capture not only social knowledge but also power relations among the resource persons. The secondary data is collected from documents and updates from the three governance arrangements, in the form of books, journal articles, reports related to sustainable palm oil issues, blogs of international research organisations, and news media.

In using the term 'state', we acknowledge that the state is not a monolithic entity. Vertically, the state has national and local levels, which might take different positions on an issue. Horizontally, the state has different agencies with different mandates; nationally, they exist as ministries and non-ministerial agencies, while in the local level we might also find agencies coordinated by the district, provincial or national level. Inside individual state entities, state officials may take different positions. When this occurs, we refer to the official position as that which is taken by state actors from the agencies that assume responsibility of the sector concerned.

The term 'non-state' that we use refers to different kinds of organisations and initiatives that exist beyond the state's domain, including NGOs, companies and community organisations. Non-state actors represent a range of interests and discourses with activities take place at local to global levels, actors that joined the steering of global affairs with nationstates (Nasiritousi et al., 2016; Koenig-Archibugi and Zürn 2006). Their power stems from a legitimacy and an ability to invoke moral claims, their knowledge and expertise, their access to networks, their access to key agents and decision-making processes, and their access to resources and position in the global economy. In this article, we associate intergovernmental agencies, which are often perceived as part of the state, as non-state actors as long as they do not assume legal roles with or without the state.

We use the terms 'state' and 'government.' Both terms are often used interchangeably and are used to explain the same thing; however, in some cases they assume different meanings. To explain this, we refer to some references. Robinson (2013) recommends that the 'state' be seen as a jurisdiction entity of the international legal system while 'government' is the exclusive coercive organisations for making and enforcing certain group decisions. Rocha (2008) argues that the 'state' is the whole political society including government that consists of executive, legislative and judicial functions. Meanwhile, 'government' is a political group that performs an executive function and manages various kinds of interventions following the direction of the state. Scruton (2007) defines the 'state' through its four components: (i) association among persons for the ends of government, (ii) legal organization; (iii) attachment to a particular territory over which jurisdiction is exercised; and (iv) personification as a juristic person in international law and a kind of quasi-person in popular thinking. Meanwhile, 'government' forms a state by exercising influence and control through law and coercion that might be perceived as a means to order, or as an end for social 
existence, with compromises between these two. Reflecting on these literatures, we summarise that 'state' is an entity in organising a society internally and externally while 'government' it is an administration that is established for arranging the implementation of state's regulations.

\section{The responses of the Indonesian state}

The roundtable on sustainable palm oil (RSPO)

In 2002, World Wide Fund (WWF) approached palm oil buyers - Aarhus, Golden Hope, MPOA, Migros, Sainsbury and Unilever - to establish RSPO and develop credible criteria for sustainable palm oil production (Omont 2005). RSPO formulated its objective as 'to promote the growth and use of sustainable palm oil through cooperation within the supply chain and open dialogue with its stakeholders' (RSPO General Assembly 2015). Until 30 June 2016, RSPO had 2941 members ranging from oil palm growers, processors and traders, manufacturers of consumer goods, retailers, banks and investors, environmental and social NGOs, academia, research and development organisations, and donors and sponsors. The 1373 ordinary members consist of 633 consumer goods manufacturers, 462 palm oil processors or traders, 155 oil palm growers, 64 retailers, 32 environmental NGOs, 14 banks and investors, and 13 social NGOs (RSPO 2016).

Being established as a private governance arrangement, RSPO approached the Indonesian state to implement the second principle on regulation compliance and smallholders certification (RSPO 2013). A RSPO Indonesian Liaison Office (RILO) was established on 1 December 2006 to work on smallholder engagement, to develop a national interpretation of RSPO principles and criteria $(\mathrm{P} \& \mathrm{C})$ and their trial implementation, and to communicate with stakeholders (RSPO 2007; RSPO Indonesia Liaison Office 2008). RILO established the Indonesian National Interpretation Working Group (INA NIWG) on 11 January 2007 to facilitate discussion on the draft of a national interpretation that had been submitted by the Indonesian Palm Oil Association (GAPKI) in July 2006 (Dharsono and Zulfikar 2007). INA NIWG involved several state agencies, namely the National Land Agency (BPN), the Ministry of Industry, the Ministry of Forestry in Group 1 (Legal, License and Social Issues Group), the Ministry of Agriculture in Group 2 (Environment and Natural Resources) and Group 3 (Agronomy and Mill Practices), the Ministry of Environment in Group 2, and the Ministry of Trade in Group 4 (Economics and Labour). RILO also developed the Indonesian National Smallholder Working Group (INA SWG) in early 2007 (Darussamin 2011). INA SWG cooperated with the Ministry of Agriculture on the RSPO standard.

The interactions in 2006-2009 are considered a modest involvement, which ended after the Indonesian state developed ISPO (Wijaya and Glasbergen 2016). ISPO is perceived as an act of reclaiming the state's authority in governing the palm oil sector (Hospes 2014; Wijaya and Glasbergen 2016; C. Brandi et al. 2013). The development of ISPO altered the interaction between the Indonesian state and RSPO from implicit recognition to explicit disqualification (Wijaya and Glasbergen 2016; Hospes et al., 2014).

However, the development of ISPO did not end the interaction between the Indonesian state and RSPO. The National Development Planning Agency (BAPPENAS) encouraged RSPO P\&C implementation together with ISPO strengthening and regulation enforcement (Haryana et al., 2010).The Vice Minister of Agriculture expected that RSPO would recognise ISPO as a requirement to fulfil its second principle on compliance with national 
regulations (Subagyo 2013). Some similarities are identified between RSPO and ISPO that could become the basis for a joint audit (Gillespie and Harjanthi 2012; Suharto et al. 2015). The Vice Minister of Trade spoke in the RSPO European roundtable in 2014 and proposed collaboration in developing a joint-standard available for non-RSPO members (RSPO 2014). This cooperation was important as ISPO faced challenges in getting international market recognition. Moreover, the Ministry of Agriculture provides a room for RSPO's Indonesian Smallholder Working Group (INA-SWG) meetings and training sessions where the Ministry's staff members always participate (interview 16). RSPO officials mentioned this facilitation was possible based on good personal relationship between RSPO's advisor and the Ministry's officials, as the advisor is a retired officer from the Ministry (interview 16).

When these limited interactions occurred, RSPO was often criticised by state officials. RSPO was considered slow in facilitating Indonesia's efforts to meet ambitious climate change targets (Suharto 2010). Several times, in speeches, Indonesian state officials also claimed that RSPO was established to serve the interests of Western countries.

\section{The Indonesia palm oil pledge (IPOP)}

IPOP is a collaborative pledge facilitated by KADIN as a response to President Yudhoyono's call for private sector transformation to end deforestation, a call delivered in the keynote speech at the Tropical Forest Alliance meeting (Butler 2013). The members of KADIN's Sustainable Business Group, who were mostly palm oil companies, delivered this by inviting the key staff members of Indonesia's REDD Taskforce and NGOs such as Greenpeace, Rainforest Action Network, and WWF (interview 9), to develop a pledge. This pledge provided a joint-platform for member companies that had previously developed sustainability commitments to inspire other companies towards a similar mission.

The pledge was signed on 24 September 2014 in New York during the Climate Summit, which was facilitated by the United Nations General Assembly. Four leading palm oil companies (Golden Agri Resources, Wilmar International Limited, Cargill and Asian Agri) signed the pledge that was witnessed by then-President Yudhoyono (Harfenist 2014). Two more leading palm oil companies later followed, Musim Mas (March 2015) and Astra Agro Lestari (February 2016).

For 1 year after the pledge was signed, IPOP operated as a KADIN program (interview 11). The launch of IPOP's Management Team on 25 August 2015 was a high-profile event with speeches from the Head of the Indonesia Investment Coordinating Board (BKPM), and the ambassadors of the United States, Norway and the United Kingdom (Rizkaprilisa 2015). Representatives from key ministries also attended the launch (interview 9,11). The Head of BKPM expected IPOP to set parameters for sustainable palm oil in Indonesia while the ambassadors expected IPOP to improve the legality of the sector (BKPM 2015). The IPOP Management Team focused on managing programs on issues concerning smallholders, land, policy reform, and communication. In implementing its program, the IPOP Management Team organised several meetings at the national and provincial level, and at the international level during the Paris Climate Summit 2015.

NGOs criticised IPOP for protecting business interests by not openly addressing palm oil expansion in peatland areas, the prevailing conversion of high carbon, and the lack of conservation of forests (Jacobson 2015; Greenomics Indonesia 2016). However, more concerning was that 2 days after the launch, IPOP faced hard resistance from key 
state officials, namely the director generals of the Ministry of Agriculture, the Ministry of Environment and Forestry, and the Coordinating Ministry of Economic Affairs (interview 9).

First, the officials suspected IPOP would develop a competitor of ISPO (interview 10,12,13). The explanation in formal documents that IPOP did not give preference to RSPO over ISPO did not help to clarify this suspicion, and BKPM's Head did not clarify his statement on expecting IPOP to develop new parameters of sustainability (interview 11).

Second, the Coordinating Maritime Affairs Minister blamed IPOP as the agent of developed countries to protect their vegetable oil markets, particularly the United States (Witoelar 2016; Chen and Yi 2016; interview 5). Moreover, the Minister argued that private sector initiatives were not relevant anymore as Indonesia and Malaysia had agreed to develop a palm oil producer council (da Costa 2015). Suspicion over an intervention by developed countries heightened as most of the signatories had headquarters outside Indonesia, while those that are based in Indonesia signed because of their buyers' pressure or due to lobbying from the US Embassy (interview 13,11).

Third, the action of IPOP signatories to stop buying FFB (Fresh Fruit Brunches) produced in the Leuser Ecosystem Area in Aceh was considered illegal, and harmful to smallholders (Jong 2015; Jong 2016), while also threatening Indonesia's palm oil sector (interview 10,13,14). Key state officials regretted this decision as it had no consideration for the steps taken by the state to exchange lands (interview 3,13). Additionally, producers with contracts up to 100,000 $\mathrm{t}$ annually argued that they had produced before the establishment of the protected area (Listiyarini 2017). This example of producers asking for state protection fits the argument of Mügge (2006) that producers often request state intervention to circumvent transnational private regulation.

Fourth, key state officials perceived the IPOP lobbying for stricter peatland and HCV (High Conservation Value) regulation as interference in Indonesian sovereignty (Jong 2015; Jacobson 2016; interview 10,13). Furthermore, a state official from the Ministry of Environment and Forestry argued that although the companies signed the pledge with international coverage, at home their conversion of biodiversity-rich areas continued (interview 14).

Fifth, key state officials regarded IPOP's activities as aiming to develop a cartel. The establishment of the Management Team heightened concerns that some people had been selected to jointly manage the leading palm oil companies (interview 11). The Ministry of Environment and Forestry rejected a request from the IPOP Management Team to meet with them, and instead asked for a meeting with member companies (interview 6,11). Furthermore, key state officials argued that having 'Indonesia' in IPOP's name indicated it was a national initiative, whereas there had never been any official endorsement of IPOP (interview 10,11).

IPOP's member companies insisted that with or without IPOP they would apply tighter sustainability requirements (Redaksi 2015a). IPOP's legal team replied that the key state officials in question resisted higher standards (Jong 2016). Together with NGOs, IPOP argued that the state used the smallholder argument as a smoke screen to protect rogue companies that have strong political influence (Jacobson 2016). Such responses seemed to challenging the state (IF Editorial Team 2016; interview 10,15). Meanwhile, IPOP achieved a notable success with Astra Agro Lestari signing the pledge, as the company had been sceptical of sustainability and had stayed outside of RSPO (Jacobson 2016). 
The IPOP Management Team was confused with such criticism as government officials were always invited and present (interview 9). Also, IPOP did not have difficulties in discussions either with ministry staff below the director general level or with local government officials. The Management Team believed that the media exaggerated the conflict. Furthermore, the government did not criticise similar initiatives such as InPOP and PisAgro. With such tension, KADIN's figureheads, who had good relations with the Indonesian state, did not want to facilitate discussion with key state officials (interview 7,11).

The situation became more difficult in October 2015 as the Director General of Plantation demanded IPOP's suspension as it violated the Indonesian Constitution (Redaksi 2015b; Arshad 2016). Though, state officials found it was not easily done (Arshad 2016; Jong 2016).

Meanwhile, the KPPU (Business Competition Supervisory Commission, the Indonesian's antitrust commission), investigated IPOP for cartel practices by excluding producers that could not comply, and thereby effectively strengthening giant companies (Amin 2017). KPPU threatened to penalise each IPOP members with a fine of Rp. 125 billion if they were indicted for cartel practice (Nurmayanti 2016). The KPPU's allegation was not taken seriously by IPOP member companies since Indonesia's antitrust regime was weak, while incompliant suppliers could sell their FFBs to other companies (Jacobson 2015). However, the allegation by KPPU was a sensitive issue for companies linked to the US and Singapore, which finally decided to disband IPOP in June 2016 (Michail 2016; interview 9). In its disbandment press release, IPOP stated that its ideas had been adopted by the Indonesian state in policies for a palm oil moratorium, establishment of a Peat Restoration Agency, and ISPO strengthening. Environmentalists considered the disbandment as a backward step, resulting from state officials' not seriously supporting the President's fight against forest and haze, and preferring weaker standards (Michail 2016; Poynton 2016; Shah 2016).

The Indonesian state's position was perceived as defending sovereignty (IF Editorial Team 2016a; IF Editorial Team 2016b). Some people linked the assertiveness towards IPOP with the emergence of new nationalism that, according to Aspinall (2015), sees Indonesia becoming increasingly averse to foreign interference and demanding greater international recognition of its power and status under President Joko Widodo.

\section{The Indonesia palm oil platform (InPOP)}

InPOP is a multi-stakeholder platform established in October 2014 as a collaboration of the Indonesian Government, the United Nations Development Programme (UNDP) and related stakeholders (Suharto et al. 2015). InPOP aims to work with the Indonesian state, as the primary stakeholder, in developing a national long-term action plan, addressing root causes limiting Indonesia's sustainability, influencing government to harmonise policies, and improving partnership with existing initiatives. InPOP invites very diverse stakeholders from different governance levels, public and private, as listed in Appendix 2.

Unlike in private voluntary sustainable governance, where non-state actors played a dominant role, InPOP gradually transfers leadership to the Indonesian state, particularly after recognising smallholder issues need active state involvements (Bovarnick et al., 2015). It is widely known that UNDP played an active role in approaching the Indonesian state (interview 6,7,10,11,13). Indeed, UNDP approached the Ministry of Agriculture and identified the state's concerns in palm oil sustainability issues (interview 1). Based on this, four working groups in InPOP were developed, in smallholders' capacity and productivity, 
environmental monitoring and management, governance and land conflict mediation, and ISPO's strengthening and market access (Jacobson 2015). InPOP asked the Agriculture Minister to appoint directors from the Directorate General of Plantation to lead the working groups. In strengthening ISPO, InPOP assists state officials in collecting data on regulation implementation and their obstacles (interview 2,3,8). InPOP developed an inter-ministerial steering committee and, by doing so, helps the Ministry of Agriculture to assume its leadership in palm oil sustainability.

Regarding smallholder issues, InPOP aims to reach 4.4 million hectares of smallholding plantations, which is almost a half of Indonesia's total oil palm plantation area (Salim 2014). To achieve this, InPOP implemented the first project in ISPO certification for smallholders in Riau involving 2200 smallholders from six palm oil cooperatives, and later implementations took place in South Sumatra and West Kalimantan (UNDP 2015). Regarding legal compliance, state agencies and other stakeholders at InPOP's October 2015 meeting recommended the acceleration of smallholder permits, in the form of STDB, a Smallholder Plantation Registration Letter, and SPPL, an Environmental Management and Monitoring Consent Letter. In January 2016, IPOP organised a meeting to discuss smallholder financing schemes.

The meeting in October 2015 considered the complicated tenure system, limited data and spatial mapping, and regulation for developing plantations in degraded lands that had been allowed since 2010. In November 2015, InPOP discussed improving smallholders' legal rights to land through the Committee for Inventory of Land Control, Ownership, Use and Utilization (IP4T Committee), a committee that facilitates changing land status for areas where the local community had lived for a long time but where the land was incorrectly mapped as forest. In May 2016, InPOP facilitated discussions for bridging a forest protection concept recognised in Indonesian law with HCVs recognised internationally; this became a major issue in strengthening ISPO (Hospes 2014; C. Brandi et al. 2013; Wijaya and Glasbergen 2016). In spite of this difference, in general the Indonesian regulations have accommodated many HCV principles (Suharto et al. 2015). In November 2016, the InPOP taskforce on HCV facilitated the revision of the HCV Indonesia Toolkit, developed earlier by international NGOs. The discussion on land and HCV issues addressed criticisms where state officials often argued that demanding recognition of international concepts had ignored the legal system embedded in Indonesia regulations (interview 2,15).

Collaboration between InPOP and the Indonesian state has been working well to date. Being hosted by the Ministry of Agriculture improves InPOP's effectiveness and its ability to approach other state agencies. However, some respondents observed that its establishment under UNDP's project arrangement is a liability since it might cease upon the project's completion if the state is not interested in developing it further (interview 6,10,11). The meetings organised by InPOP are often not results-orientated (interview 10,15), but this is not surprising since immediate results from a policy program such as InPOP might not be immediately evident (interview 8). Also, state officials often show an unconvincing commitment to work beyond an ad-hoc approach (interview 6,7). Taking into account the limitations of InPOP, the contribution of IPOP to sustainability governance on palm oil issues needs more observation. 


\section{Discussion}

The three case studies show that the Indonesian state responds differently to the various non-state governance initiatives in sustainable palm oil. These responses show that the Indonesian state acts beyond a simplified assumption that it would always support the palm oil sector against sustainability issues raised by external actors. To unravel the Indonesian state's different responses, the following discussion is presented in three parts: governance interactions that occur between the state and non-state sustainability initiatives, the underlying mechanisms of those interactions, and the implications for business.

\section{Governance interactions}

To unravel the Indonesian state's responses to non-state sustainability initiatives, we use the TBGIF to observe the interaction. The analysis characterises four types of interactions: competition, coordination, co-optation, and chaos.

1. RSPO maintained the mechanisms of a transnational private initiative to develop governance mechanisms, concerned at the inability of producing states to address the impacts of palm oil expansion. This belongs to co-optation character but from the nonstate actors' side. Later, the state was invited to be involved in the interpretation of RSPO principles and criteria, and in smallholder certification. The invitation allowed for the character of coordination to emerge. The Indonesian state, almost at the same time, recovered from the economic crisis and wanted to return to its development interventions. Consequently, the state experienced tension between being in a new environment demanding progressive change and their interest in increasing its developmental role. With this tension, the state recognised the importance of addressing sustainability issues and decided to develop a national standard in ISPO, which shifted the character to competition. In developing ISPO, the state realised it was difficult to obtain international recognition as RSPO had and, therefore, attempted to maintain and recover its coordination character. However, with the prevailing tension and tendency to preclude RSPO mechanisms, the coordination survives only through interaction at a personal level.

2. IPOP emerged with high-level support both from the Indonesian state, donor countries and supranational organisations, which enabled it to build a high profile both internationally and nationally. The situation changed after the new government emerged in 2014, where having a high profile became a liability. Meanwhile, internally IPOP was not ready and KADIN did not support building relations with state officials. The interaction character changed from coordination to chaos with severe criticism from the key state actors in the palm oil sector. With this interaction characterised as chaos, the key state officials aimed for the co-optation of IPOP, while IPOP continued its good relationships with state actors from lower echelons and local government. The co-optation was possible upon an antitrust allegation by KPPU, leading to disbandment of IPOP by its members.

3. UNDP approached the Indonesian state about developing InPOP and positioned itself as a bridge between the state and non-state initiatives. The state welcomed the assistance of UNDP, as on its own, the state experienced significant challenges in coordinating with stakeholders such as RSPO and NGOs. The coordination type interaction strengthened over time as InPOP helped the Ministry of Agriculture develop the leadership needed on sustainable palm oil issues. 
The summary of the responses can be seen in Tables 1, 2 and 3, following:

\section{Underlying mechanisms of the interactions}

The responses, as seen in the table, involve dynamic underlying mechanisms. First, actors from different echelons in a specific agency might also give different responses. In some cases, invalidation might be expressed by state officials from higher positions, and in the absence of further action, the responses given would become the state's formal position. Moreover, the responses at the institutional level might differ with responses at the individual level. In the case of RSPO, personal relationships help to maintain some cooperation. IPOP could not rely on such individual relationships with the lack of support from KADIN figureheads to mend the relationships with key state officials. Different responses given by state actors link to the discussion about hidden and public transcripts in avoiding hegemony (Scott 1990). In the same agency, some state actors might support non-state actors to further progress with sustainable palm oil initiatives (in the cases of RSPO and IPOP), while some state actors are not necessarily committed to having more progressive steps (in InPOP's case). Different responses by state actors emerged without directly confronting the norms exhibited by their leaders. In the case of resistance to agenda of nonstate initiatives, such aversion would not lead to face-to-face confrontation with the state as long as the non-state initiatives were able to maintain relationships at different levels

Table 1 Governance Interactions between the Indonesian State and RSPO: from Coordination to Competition, and from Competition to Limited Coordination

\begin{tabular}{|c|c|c|c|c|}
\hline & Agenda setting & Rule formation & Implementation & Evaluation \\
\hline Period & 2003-2006 & $2006-2008$ & 2009-now & 2010-now \\
\hline Micro-level & No interaction & $\begin{array}{l}\text { Coordination based on } \\
\text { personal relationships } \\
\text { among officials }\end{array}$ & $\begin{array}{l}\text { Limited coordination } \\
\text { based on personal } \\
\text { relationships among officials }\end{array}$ & $\begin{array}{l}\text { Limited } \\
\text { coordination } \\
\text { based on personal } \\
\text { relationships } \\
\text { among officials }\end{array}$ \\
\hline Meso-level & No interaction & $\begin{array}{l}\text { Coordination through } \\
\text { discursive articulation } \\
\text { of principles and criteria }\end{array}$ & $\begin{array}{l}\text { Competition emerged after } \\
\text { the Indonesian state } \\
\text { decided to develop the } \\
\text { national standard (ISPO). } \\
\text { The state developed } \\
\text { competition through } \\
\text { imitation by following } \\
\text { steps for formulating RSPO. } \\
\text { The state also developed } \\
\text { competition through } \\
\text { niche-carving by referring } \\
\text { to national regulations } \\
\text { related to sustainable palm } \\
\text { oil principles. } \\
\text { Often the state developed } \\
\text { competition through } \\
\text { confrontation as the state } \\
\text { officials criticised RSPO in } \\
\text { their formal speeches. }\end{array}$ & $\begin{array}{l}\text { There were signs of } \\
\text { developing } \\
\text { coordination } \\
\text { based on } \\
\text { Indonesian state } \\
\text { actors' awareness of } \\
\text { RSPO's international } \\
\text { recognition, which } \\
\text { was not easily } \\
\text { gained with ISPO. } \\
\text { The state actors } \\
\text { were even } \\
\text { enthusiastic for } \\
\text { coordination for } \\
\text { harmonisation of } \\
\text { both standards. } \\
\text { However, so far this } \\
\text { has resulted in only } \\
\text { limited coordination. }\end{array}$ \\
\hline Macro-level & $\begin{array}{l}\text { Co-optation by } \\
\text { non-state actors } \\
\text { to the palm oil } \\
\text { producing countries } \\
\text { is considered a failure } \\
\text { in addressing social } \\
\text { and environmental } \\
\text { impacts. }\end{array}$ & No interaction & No interaction & $\begin{array}{l}\text { Not enough } \\
\text { information }\end{array}$ \\
\hline
\end{tabular}


Table 2 Governance Interactions between the Indonesian State and IPOP: from Coordination to Competition, and from Competition to Chaos, and from Chaos to Co-optation

\begin{tabular}{|c|c|c|c|c|}
\hline & Agenda setting & Rule formation & Implementation & Evaluation \\
\hline Period & 2014 & $2015-2016$ & $2015-2016$ & Middle of 2016 \\
\hline Micro-level & No interaction & $\begin{array}{l}\text { Lack of support from } \\
\text { KADIN figureheads with } \\
\text { good relationships with } \\
\text { the key state agencies } \\
\text { related to palm oil issues }\end{array}$ & $\begin{array}{l}\text { Lack of support from } \\
\text { KADIN figureheads that } \\
\text { have good relationships } \\
\text { with the key state } \\
\text { agencies related to } \\
\text { palm oil issues }\end{array}$ & No interaction \\
\hline Meso-level & No interaction & $\begin{array}{l}\text { Coordination for } \\
\text { developing IPOP as a } \\
\text { high-profile initiative in } \\
\text { the national and inter } \\
\text { national levels } \\
\text { Co-optation by the } \\
\text { Indonesian state through } \\
\text { the key state officials } \\
\text { responsible in the } \\
\text { development of the } \\
\text { palm oil sector }\end{array}$ & $\begin{array}{l}\text { Competition through } \\
\text { confrontation as IPOP } \\
\text { continued operating } \\
\text { despite being criticised } \\
\text { heavily by key state } \\
\text { officials in the palm oil sector } \\
\text { Competition through } \\
\text { threats occurred as key } \\
\text { state officials wanted to } \\
\text { disband IPOP. } \\
\text { Chaos as IPOP faced } \\
\text { uncertainty due to vocal } \\
\text { criticism from key state } \\
\text { officials, but it did } \\
\text { not have any problems } \\
\text { working with ministerial } \\
\text { officials from the lower } \\
\text { echelons and local } \\
\text { government officials; } \\
\text { meanwhile IPOP was } \\
\text { unsuccessful in getting } \\
\text { clarification of their positions. }\end{array}$ & $\begin{array}{l}\text { Co-optation } \\
\text { as the antitrust } \\
\text { investigation } \\
\text { became a } \\
\text { sensitive issue } \\
\text { for member } \\
\text { companies; } \\
\text { they finally } \\
\text { decided to } \\
\text { disband IPOP. }\end{array}$ \\
\hline Macro-level & $\begin{array}{l}\text { Coordination for } \\
\text { formulating a pledge } \\
\text { between business actors } \\
\text { (the sustainable development } \\
\text { group of KADIN), state actors } \\
\text { (REDD+ Taskforce and BKPM), } \\
\text { and civil society actors } \\
\text { (environmental NGOs) }\end{array}$ & No interaction & $\begin{array}{l}\text { Chaos as IPOP faced an } \\
\text { antitrust investigation } \\
\text { from KPPU }\end{array}$ & No interaction \\
\hline
\end{tabular}

(micro, meso and macro), while remaining concerned with continued program implementation.

Second, these responses depend on pathways built by non-state initiatives. In these pathways, two factors are relevant to determining interactions, namely (1) positioning of the non-state initiatives, and (2) strategies to communicate with the state. The Indonesian state could not intervene in RSPO too much. On positioning, RSPO had an advantage from its global and market recognition that was difficult for ISPO to match. On communicating, RSPO maintained an image of governance among private actors that made disqualifying statements from state officials less relevant. IPOP from the beginning had a position as high-level initiatives with strong support from global organisations, donor countries, and some state officials. However, this position also brought with it a liability in developing communication, as it was accompanied by the perception of having strong linkages with the former presidential administration and the agendas of foreign countries. With this vulnerability, the leading figures in KADIN that potentially had leverage to open communication with state high officials did not give strong support. UNDP adopted a different strategy by initiating InPOP as a consultative platform with the Ministry of Agriculture. The state was involved step-by-step in its establishment and finally achieved recognition for leading the initiative. The case of InPOP confirms the argument that intergovernmental organisations have the potential to perform significant intermediary roles, 
Table 3 Governance Interactions between the Indonesian State and InPOP: staying in Coordination

\begin{tabular}{|c|c|c|c|c|}
\hline & Agenda setting & Rule formation & Implementation & Evaluation \\
\hline & 2014 & 2014-2015 & 2015-now & \\
\hline Micro-level & No interaction & No interaction & $\begin{array}{l}\text { Dissatisfaction from some } \\
\text { state officials with the } \\
\text { progress and clarity of } \\
\text { InPOP's programs }\end{array}$ & $\begin{array}{l}\text { Not enough } \\
\text { information }\end{array}$ \\
\hline Meso-level & No interaction & $\begin{array}{l}\text { Coordination to develop } \\
\text { the multi-stakeholder } \\
\text { forum involving actors } \\
\text { from government, } \\
\text { development partners, } \\
\text { private sector, and civil } \\
\text { society organisations } \\
\text { Coordination through } \\
\text { division of labour between } \\
\text { the Ministry of Agriculture } \\
\text { and UNDP }\end{array}$ & $\begin{array}{l}\text { Coordination in } \\
\text { addressing issues relating } \\
\text { to smallholders, land, HCV, } \\
\text { and inter-ministerial } \\
\text { collaboration } \\
\text { Further coordination was } \\
\text { developed to shift the } \\
\text { leadership to the } \\
\text { Ministry of Agriculture. }\end{array}$ & $\begin{array}{l}\text { Not enough } \\
\text { information }\end{array}$ \\
\hline Macro-level & $\begin{array}{l}\text { Coordination between an } \\
\text { international agency (UNDP) } \\
\text { and the Indonesian state } \\
\text { (Ministry of Agriculture) } \\
\text { motivated by awareness of } \\
\text { the importance of the state's } \\
\text { role in improving regulation } \\
\text { and addressing smallholder } \\
\text { issues }\end{array}$ & No interaction & No interaction & $\begin{array}{l}\text { Not enough } \\
\text { information }\end{array}$ \\
\hline
\end{tabular}

encourage new schemes, or support existing ones that advance public goals by leaning on state consent (Bernstein 2011; Abbott 2012).

Third, responses change over time, which we observed in the relationship between these changes and the changing of Indonesia's political economic situation. The palm oil sector made a significant contribution to the recovery of the Indonesian economy following the 1997 Asian Crisis (Susila 2004). The economic recovery enabled the state to bring back its role in facilitating palm oil sector development, but this time the state faced increasing pressure to address sustainability issues (Pramudya et al., 2017a). The reluctance to develop further partnerships within RSPO occurred at the onset of the rising confidence of the state to improve its facilitation roles. In the meantime, Varkkey (2016) mentioned that patronage politics from business had increasing influence on policy makers, contributing to the palm oil expansion at the expense of environmental and social needs. Patronage politics partially provided reasons for the objection of the Indonesian state in supporting the disqualification of palm oil producers that could not comply with IPOP's pledges; this was done with the reasoning that it would protect smallholders, yet meanwhile the state did not provide reasonable solutions directing smallholders towards improved sustainable development practices. The attitude used by InPOP to approach and strengthen the Ministry of Agriculture's role in the sustainable palm oil issue received a positive response as it did not conduct open confrontation with the government.

Fourth, the responses of the state depend on the position and leadership style of the state's administration. The Yudhoyono administration, from 2004 to 2014, adopted a strong vision for promoting sustainable development that burnished its international image. However, the administration contended with an implementation deficit due to weak leadership, indecisiveness and allowing political financing from natural resource exploration (Anderson et al., 2015). During these years, the state's responses to non- 
state actor sustainability initiatives that emerged including modest involvement in RSPO, establishing ISPO but with limited authority under the Ministry of Agriculture, and witnessing the high-profile of pledge signing of IPOP in the Paris Climate Conference. In 2014, with the new government under President Widodo's administration, there emerged an increasing reluctance to entertain foreign interference, promoting economic nationalism, and demanding greater international recognition (Aspinall 2016). However, the Widodo administration exhibited inconsistency with unpredictable responses and adhoc management (Warburton 2016). Under this administration, the confusing responses to IPOP occurred alongside a suspicion that it had become a vehicle of foreign interests. Such issues related to sovereignty might stimulate the Indonesian state's strong reaction with could result in repressive approach (Pramudya et al., 2017b) However, the humble approach of UNDP in establishing InPOP that has similar programmes with IPOP resulted in a positive response from the state. This situation shows that leadership styles and orientation affect the state's responses, and business that are aware can develop more effective collaboration with the state.

The changing and, sometimes, unpredictable responses from the state raises an issue about what would be a suitable role for the state. Evans (1995) argued that beyond limiting itself to regulation, the state could perform an important facilitation of developing the economy by supporting business. However, when the situation changes, then business would have to reorient themselves to contemporary conditions. Rather than leaving it to the market mechanism, the state plays an important role in preparing business to cope with the changes. The Indonesian palm oil sector itself emerged from active facilitation of the state in the past (Rival and Levang 2014; Casson 1999; Pramudya et al., 2017a), and therefore seeing the state as an important agent for sector transformation is undeniable.

\section{Business implications}

In analysing the implications of business involvement in non-state sustainable palm oil initiatives, we can highlight six points. First, business involvement in sustainability initiatives does not only aim to respond to market demands. Business benefits most from the opportunity to work side-by-side with other stakeholders and public agencies to address sustainability issues. In the Indonesian palm oil sector with regulation complexity, political sensitivity, and the participation of small-scale producers, such collaboration becomes an important strategy. By participating in non-state sustainability initiatives, business can develop collective action in a closer interaction with policy makers. Companies that are involved in non-state sustainability initiatives have opportunities to share their challenges, and together in the initiatives, lobby policy makers for regulatory changes or even for the state's support in facing international pressure. This proximity, however, demands better engagement with state agencies and officials. Particularly during political transition, companies have to read the situation and not remain stuck in obduracy. The lack of careful attention to domestic political transition would result in failure regardless of the immeasurable support provided by donor countries and NGOs.

Second, business needs to be aware of the variety of orientation and political positioning across governmental levels. In the case of IPOP, business assumed strong political support in the pledge signing witnessed by the President, in the presence of high-level officials from key ministries at IPOP events, and in the keynote speech by high-level state officials 
at the Management Team's launching ceremony. However, all of these proved insufficient when communication with the Directorate General of Plantation, the focal authority in the plantation sector, was not developed well. IPOP was not aware that the presence of ministerial officials did not always automatically means that their superintendents agreed. Indeed, with their absence, some state's high officials might feel that they were not involved.

Third, initiatives at individual company level are important. Beyond demonstrating a commitment for self-improvement, individual company initiatives might become a survival strategy in developing multilevel interactions with the state. When a company engages in multilevel interactions, the tension and conflict in the level that involves more stakeholders could be mitigated by developing relationships at the level where fewer stakeholders are involved, or by further isolating the interaction between the individual company and the state officials. IPOP member companies, rather than stubbornly involving themselves in a conflictual situation with the state, decided to refer back to companies' individual pledges. The implementation of individual pledges can address concerns over their commitment to improve business practices rather than elongating political tensions.

Fourth, non-state sustainability initiatives can reduce the risk for direct conflict with the state by developing internal capacity for maintaining the relationship at the personal level, despite times of intensified conflict with the state. One way to build such capacity is to hire persons that have good personal relationships with the state officials, as we see in RSPO. However, this was not the case with IPOP where KADIN officials did not want to liaise with the government. Maintaining relationships at the personal level can reduce the risk of direct conflict with the state.

Fifth, in arranging non-state initiatives, third parties might play important roles in facilitating state engagement. In the case of InPOP, UNDP provides an excellent example for this task. The Indonesian state could not simply block the path of UNDP in developing such an initiative, due to its position as an intergovernmental organisation. On the other hand, UNDP seemed know how to engage the state effectively from the beginning and at the time gave the Indonesian state a larger responsibility in progressing the InPOP agenda.

Lastly, the participation of business in non-state sustainability initiatives often comes with the expectation that they will perform beyond legal requirements. This can be seen in our cases, where NGOs often brought suspicion and mounted pressure on business without considering the needs of business to adjusting their operations and learn from past mistakes. One needs to be aware that business becomes pro-active in their participation for sustainability governance if they perceive the initiatives are fair, and offer sufficient benefit, such as distinguishing themselves from competitors, providing access to markets, or anticipating regulatory change (Rondinelli and Berry 2000; Abbott 2012; Kordos and Vojtovic 2016). On the one hand, an awareness of business limitations does not need to limit the scope of commitment for improving sustainability. On the other hand, companies need to look beyond a business-as-usual approach, and have a basis on concerns about the urgent actions for saving the planet. Business should not limit itself relying on a narrow CSR agenda and searching for regulatory loopholes (Gillespie 2012; Weyzig 2009; Azhar et al. 2017). Moreover, rather than asking for additional protection from the state, business could contribute in publicprivate partnerships through providing material resources, managerial authority, and expertise where they excel, according to Abbott (2012). 


\section{Conclusion}

Business, in its involvement with non-state sustainability initiatives, needs more than straightforward ways to deal with the pressures of addressing environmental and social impacts. Analysis of governance interactions that generate responses from the state towards non-state sustainability initiatives plays important roles in formulating and implementing business strategy. Our cases show that these responses are not stable but are changing dynamically. Between the Indonesian state and RSPO, the character started as co-optation (from the non-state actors' side) and changed to coordination. This coordination later changed to competition and then to coordination, albeit a limited coordination. With IPOP, the character changed from coordination to chaos, and finally to co-optation. The character of interaction between InPOP and the Indonesian state persisted as coordination. Dynamism is also observed within the state, across governance levels, and in terms of personal levels compared to institutional levels. Across time, this dynamism is also present in pathways developed between the Indonesian state and the non-state initiatives.

These changing responses depend on underlying mechanisms within the governance interaction. Such mechanisms include dynamic interactions between the state and private governance arrangements, the varying positions of actors, the internal dynamics within state agencies, the pathways of the non-state sustainable palm oil initiatives, and the political economy. Beyond the dynamism outlined in the TBGIF by Eberlein et al. (2014), these interactions are not only different from one governance arrangement to another, but also alter over place and time within one arrangement. Considering the dynamic nature of the interactions between the Indonesian state and the non-state initiatives in sustainability, it is reasonable to expect that the current configuration is not final, and further changes are likely.

The cases presented in this article show that business has to develop an effective strategy in participating in non-state sustainability initiatives. Such a strategy could be built by applying flexible positioning in facing political transition, identifying and checking whether good communication has been developed with key state actors, developing multilevel playing fields from institutional to individual and personal levels, and seeking third-party assistance in facilitating communication with the state.

This research on governance interaction has been limited in four ways: the time-span of the observation (until 2016), the space for describing activities of the non-state sustainability initiatives, the availability of comprehensive evaluation of the initiatives, and resources available (including time and finances) to support the implementation of the research. Rather than becoming a stumbling block in understanding the topic of governance interaction, these limitations open opportunities for further research. First, as the current configuration between state and non-state initiatives is not final, researchers in the future can look further into the dynamism developed after 2016. Second, the willingness of the state to capitalise on expertise generated from involvements in these initiatives could be explored. Third, the network of innovation and improvement created from the interaction of individual company commitments to non-state sustainability initiatives could be examined. Finally, reflections by business actors on the interaction between the state and non-state sustainability initiatives could be surveyed. 


\section{Appendix 1}

Table $\mathbf{4}$ List of Interviews

\begin{tabular}{llll}
\hline Interview & Interviewees & Mode of interview & Date \\
\hline 1 & Former Official of the Ministry of Agriculture & Direct meeting & 03/03/2015 \\
2 & ISPO Commission Chair (then) & Direct meeting & 29/07/2015 \\
3 & ISPO Commission Chair (now) & Direct meeting & 29/01/2016 \\
4 & Palm Oil Association & Direct meeting & 29/01/2016 \\
5 & International NGO & Direct meeting & $19 / 02 / 2016$ \\
6 & IPOP Member Companies 1 & Teleconference & $01 / 05 / 2016$ \\
7 & IPOP Member Companies 2 & Teleconference & $01 / 05 / 2016$ \\
8 & InPOP Consultant & Teleconference & $06 / 05 / 2016$ \\
9 & IPOP Management & Teleconference, Group interview & 20/06/2016 \\
10 & Coordinating Minister of Economic Affairs Official 1 & Direct meeting & $29 / 12 / 2016$ \\
11 & Former Indonesia Trade and Industry Chamber Staff & Direct meeting & $04 / 01 / 2017$ \\
12 & Coordinating Minister of Economic Affairs Official 2 & Direct meeting & $10 / 01 / 2017$ \\
13 & Ministry of Agriculture Official & Direct meeting & $14 / 11 / 2016$ \\
14 & Ministry of Environment and Forestry Official & E-mail & $09 / 03 / 2016$ \\
15 & Ministry of Agriculture Officials & Direct meeting & $14 / 11 / 2016$ \\
16 & RSPO officials & Direct meeting & 20/05/2015 \\
\hline
\end{tabular}

\section{Appendix 2}

Table 5 InPOP Stakeholders

\begin{tabular}{ll}
\hline Sector & Organisation \\
\hline Government & Ministry of Agriculture, Coordinating Ministry of Economic Affairs, Indonesian Sustainable \\
& Palm Oil Secretariat (ISPO), Ministry of Environment and Forestry, The National \\
& Development Planning Agency (Bappenas), The National Land Agency (BPN), Ministry of \\
& Cooperatives and SMEs, Representatives from local government: Riau, South Sumatra, \\
& West Kalimantan \\
Development & United Nations Development Programme (UNDP), United Nations Children Fund (UNICEF), \\
Partners & Swiss Secretariat for Economic Affairs (SECO), Solidaridad, The Netherlands Development \\
& Organisation (SNV) \\
Private Sector & Wilmar International Limited, Indonesian Palm Oil Producers Association (GAPKI), Indonesia \\
& Palm Oil Board (DMSI), IKEA, Mondelez International, Sucofindo, Tuv Rheinland, PT Astra \\
& Agro Lestari Tbk, PT Sinar Mas Agro Resources and Technology Tbk (SMART), Asian Agri \\
& Group, Cargill Indonesia, Goodhope Plantations, ANJ Group, The Roundtable on Sustainable \\
& Palm Oil (RSPO) \\
& Sawit Watch, World Wildlife Fund (WWF), The Nature Conservancy (TNC), Climate Policy \\
Civil Society & Initiative (CPI), Sustainable Trade Iniative (IDH), Conservation International, Earth Innovation, \\
& Zoological Society of London (ZSL), Estates Strategic Sustainable Development Forum \\
& (FP2SB), Oil Palm Smallholders Union (SPKS), Indonesian Center for Agricultural Land \\
& Resources Research and Development (ICALRRD), Center for International Forestry Research \\
& (CIFOR), Indonesian Oil Palm Society (MAKSI), Indonesian Palm Oil Board (DMSI), Bogor \\
& Agricultural University (IPB), LPP Yogyakarta Polytechnic College \\
\hline
\end{tabular}


Authors' contributions

All authors participated in the design of the study, sequence alignment, read and approved the final manuscript.

\section{Competing interests}

The authors declare that they have no competing interests.

\section{Publisher's Note}

Springer Nature remains neutral with regard to jurisdictional claims in published maps and institutional affiliations.

Received: 30 July 2017 Accepted: 9 January 2018

Published online: 22 January 2018

\section{References}

Abbott KW (2012) Engaging the public and the private in global sustainability governance. Int Aff 88(3):543-564. https://doi.org/10.1111/j.1468-2346.2012.01088.x

Abbott KW, Snidal D (2008) The governance triangle: regulatory standards institutions and the shadow of the state. In: Mattli W, Woods N (eds) The politics of global regulation. Princeton University Press, Princeton, N.J

Amengual M, Chirot L (2016) Reinforcing the state: transnational and state labor regulation in Indonesia. ILR Rev 69(5): 1056-1080. https://doi.org/10.1177/0019793916654927

Amin, Khoirul. 2017. "Palm Oil Giants Linked to Collusion, Business Watchdog Says." Jakarta Post. http://www.thejakartapost. com/news/2016/04/15/palm-oil-giants-linked-collusion-business-watchdog-says.html. Retrieved 7 July 2016

Anderson P, Firdaus A, Mahaningtyas A (2015) Big commitments, small results: environmental governance and climate change mitigation under Yudhoyono. In: Aspinall E, Mietzner M, Tomsa D (eds) The Yudhoyono Presidency: Indonesia's Decade of Stability and Stagnation, Institute of Southeast Asian Studies, Singapore, pp 258-273

Andonova LB (2010) Public-private partnerships for the earth: politics and patterns of hybrid Authority in the Multilateral System. Global Environ Poli 10(2):25-54

Andonova LB, Betsill MM, Bulkeley H (2009) Transnational climate governance. Glob Environmental Politics 9(2):52-73. https://doi.org/10.1162/glep.2009.9.2.52

Arshad A (2016) "Jakarta Wants Oil Majors to Ditch 'Zero Deforestation' Pact." Straits Times, April 15. http://www. straitstimes.com/world/jakarta-wants-oil-majors-to-ditch-zero-deforestation-pact. Retrieved 12 Sept 2017

Aspinall E (2016) The new nationalism in Indonesia. Asia Pac Policy Stud 3(1):72-82. https://doi.org/10.1002/app5.111

Auld G, Gulbrandsen LH (2015) Diversifying nature protection: evaluating the changing tools for Forest protection in Canada and Norway. Rev Policy Res 32(6):699-722

Azhar B, Saadun N, PrideauxM, Lindenmayer DB (2017) The global palm oil sector must change to save biodiversity and improve food security in the tropics. J Environ Manage 203:457-466. doi:https://doi.org/10.1016/j.jenvman.2017.08.021

Biernacki P, Waldorf D (1981) Snowball sampling: problems and techniques of chain referral sampling. Sociol Methods Res 10(2):141-163

BKPM. 2015. "BKPM Apresiasi Inisiatif Investasi Sawit Yang Ramah Lingkungan." Siaran Pers Badan Koordinasi Penanaman Modal, August 25. http://www2.bkpm.go.id/images/uploads/file_siaran_pers/Siaran_Pers_24082015_-Investasi_Sawit_Ramah_Lingkungan.pdf. Retrieved 9 Feb 2017

Bovarnick A, Newport S, Uno T (2015) "Multinationals Cannot Prevent Palm Oil Deforestation on Their Own." Guardian, May 13. https://www.theguardian.com/sustainable-business/2015/may/13/palm-oil-indonesia-collaborationsmallholders-multinationals-government-ispo. Retrieved 22 Mar 2016

Brandi CA (2017) Sustainability standards and sustainable development - synergies and trade-offs of transnational governance. Sustain Dev 25(1):25-34. https://doi.org/10.1002/sd.1639.

Brandi C, Cabani T, Hosang C, Schirmbeck S, Westermann L, Wiese H (2013) Sustainability certification in the Indonesian palm oil sector: benefits and challenges for smallholders. Deutsches Institut für Entwicklungspolitik GmbH, Bonn

Butler R (2013) World's biggest companies lay out path toward zero-deforestation commodities. Mongabay, June 28 https://news.mongabay.com/2013/06/worlds-biggest-companies-lay-out-path-toward-zero-deforestationcommodities/. Retrieved 7 Mar 2017

Cashore B (2002) Legitimacy and the privatization of environmental governance: how non-state market-driven (NSMD) governance systems gain rule-making authority. Governance 15(4):503-529. https://doi.org/10.1111/1468-0491.00199

Casson A (1999) The hesitant boom: Indonesia's oil palm sub-sector in an era of economic crisis and political change, CIFOR Occasional Paper no. 29. CIFOR, Bogor

Chen LC, Yi LX (2016) "Post-IPOP: How Indonesia Can Lead in Palm Oil Sustainability." Jakarta Post, July 26. http://www. thejakartapost.com/academia/2016/07/26/post-ipop-how-indonesia-can-lead-in-palm-oil-sustainability.html. Retrieved 2 Aug 2016

Cutler AC (1999) Locating 'authority' in the global political economy. Int Stud Q 43(1):59-81

D’Antone, Simona, and Robert Spencer. 2015. "Organising for Sustainable Palm Oil Consumption: A Market-Based Approach. " Consumption Markets and Culture 18 (1). Taylor \& Francis: 55-71. doi:https://doi.org/10.1080/10253866.2014.899217.

da Costa AB (2015) "New Palm Oil Council Would Drop 'no Deforestation' pledge - Indonesia," October 14. http://www. reuters.com/article/2015/10/14/indonesia-palm-ipop-idUSL3N12E22820151014. Retrieved 2 Jan 2017

Darussamin, Asril. 2011. "Indonesian smallholders working group activities towards group certification of palm oil smallholders in Indonesia; presentation on Rountable 9 in Sabah."

Detomasi DA (2007) The multinational corporation and global Governance : Modelling global public policy networks. J Bus Ethics 71:321-334. https://doi.org/10.1007/s10551-006-9141-2

Dharsono, Daud, and Ismu Zulfikar. 2007. "RSPO Indonesian National Interpretation, progress overview, paper presented for session $\|$ at the 5th roundtable meeting on sustainable palm oil."

Eberlein B, Abbott KW, Black J (2014) Transnational business governance Interactions : conceptualization and framework for analysis. Regul Gov 8:1-21. https://doi.org/10.1111/rego.12030

Evans P (1995) Embedded autonomy. Princeton University Press, Princeton, N.J 
Evans P (1997) The eclipse of the state? Reflections on Stateness in an era of globalization. World Polit 50(1):62-87. https://doi.org/10.1017/S0043887100014726

Fox T, Ward H, Howard B (2002) Public sector roles in strengthening corporate social responsibility: a baseline study. The World Bank, Washington, D.C.

Giessen, Lukas, Sarah Burns, Muhammad Alif, K Sahide, and Agung Wibowo. 2016. "From Governance to Government : The Strengthened Role of State Bureaucracies in Forest and Agricultural Certification." Policy and Society 35 (1). Policy and Society Associates Ltd Partnership: 71-89. doi:https://doi.org/10.1016/j.polsoc.2016.02.001.

Gillespie P (2012) The challenges of corporate governance in Indonesian oil palm: opportunities to move beyond legalism? Asian Stud Rev 36(2):247-269. https://doi.org/10.1080/10357823.2012.685447

Gillespie P, Harjanthi RS (2012) "ISPO, RSPO: Two Sides of the Same Coin?" Jakarta Post, November 2. http://www. thejakartapost.com/news/2012/11/02/ispo-rspo-two-sides-same-coin.html. Retrieved 22 Mar 2016

Greenomics Indonesia. 2016. "Wilmar \& Musim Mas Take Hands-off Approach." IPOP-Observer, March 28. http://www. greenomics.org/docs/POP-Implementation-Report-10_Greenomics.pdf.

Gulbrandsen LH (2014) Dynamic governance interactions: evolutionary effects of state responses to non-state certification programs. Regul Gov 8:74-92. https://doi.org/10.1111/rego.12005

Handcock MS, Gile KJ (2011) On the concept of snowball sampling. Sociol Methodol 41(1):367-371

Harfenist E (2014) "'No Forests, No Cash': Palm Oil Giants Commit to Sustainability, but Will They Follow through ?" Mongabay, October 21. https://news.mongabay.com/2014/10/no-forests-no-cash-palm-oil-giants-commit-tosustainability-but-will-they-follow-through/. Retrieved 22 Mar 2016

Haryana, Arif, Jarot Indarto, and Noor Avianto. 2010. "Naskah Kebijakan (Policy Paper) Kelapa Sawit Indonesia Secara Berkelanjutan." Direktorat Pangan Dan Pertanian Kementerian Perencanaan Pembangunan Nasional/ Badan Perencanaan Pembangunan Nasional (BAPPENAS). Jakarta

Hospes O (2014) Marking the success or end of global multi-stakeholder Governance ? The rise of National Sustainability Standards in Indonesia and Brazil for palm oil and soy. Agric Hum Values 31:425-437. https://doi.org/ 10.1007/s10460-014-9511-9

Hospes O, Schouten G, Deike J (2014) Coping with the emergence of new sovereignties over sustainability: dilemmas and decision-making of the Indonesian state in a plural legal order. In: 1-17. Paper presented for ECPR joint session (10-15 April, Salamanca)

IF Editorial Team (2016a) "Can Smallholders Benefit from Palm Oil Pledge Debate?" IF Innovation Forum, February 25. https:// innovation-forum.co.uk/analysis.php?s=can-smallholders-benefit-from-palm-oil-pledge-debate. Retrieved 22 Mar 2016

IF Editorial Team (2016b) "Did the Indonesian Palm Oil Pledge Fail or Succeed?" Innovation Forum, July 7. https:// innovation-forum.co.uk/analysis.php?s=did-the-indonesian-palm-oil-pledge-fail-or-succeed. Retrieved 2 Jan 2017

Jacobson P (2015) "Palm Giants Ask Indonesian Gov't to Clear Path toward Sustainability." Mongabay, May 1. http://news. mongabay.com/2015/05/palm-giants-ask-indonesian-govt-to-clear-path-toward-sustainability/. Retrieved 22 Mar 2016

Jacobson, Philip. 2016. "Indonesian Palm Oil Giant Joins No-Deforestation Pledge amid Criticism from Politicians." Mongabay, February 18.

Jessop B (1997) Capitalism and its Future : remarks on regulation, government and governance. Rev Int Polit Econ 4(3): 561-581. https://doi.org/10.1080/096922997347751

Jong HN (2015) "Govt Opposes Zero-Deforestation Pledge by Palm Oil Firms." Jakarta Post, August 29. http://www. thejakartapost.com/news/2015/08/29/govt-opposes-zero-deforestation-pledge-palm-oil-firms.html. Retrieved 22 Mar 2016

Jong HN (2016). "Govt Promises Better Responses to Forest Fires." Jakarta Post, March 15. http://www.thejakartapost. com/news/2016/03/15/govt-promises-better-response-forest-fires.html. Retrieved 12 Mar 2017

Khan MH (2004) State failure in developing countries and institutional reform strategies. In: Annual World Bank Conference on Development Economics - Europe 2003. The International Bank for Reconstruction and Development/The World Bank, Washington, D.C., pp 165-195

Khor YL (2011) The Oil Palm Industry Bows to NGO Campaigns. Lipid Technol 23(5):102-104. doi:https://doi.org/10. 1002/lite.201100106

Koenig-Archibugi M, Zürn M (2006) New modes of governance in the global system: exploring Publicness, delegation and inclusiveness. Palgrave Macmillan, New York, N.Y. https://doi.org/10.1057/9780230372887

Kooiman, Jan and Maarten Bavinck. 2005. "The Governance Perspective." In Fish for Life: Interactive Governance for Fisheries, edited by Jan Kooiman, Maarten Bavinck, Svein Jentoft and Roger Pullin, 11-24. Amsterdam University Press. Amsterdam

Kordos, Marcel, and Sergej Vojtovic. 2016. "Transnational Corporations in the Global World Economic Environment." Procedia - Social and Behavioral Sciences 230 (May). The Author(s): 150-58. doi:https://doi.org/10.1016/j.sbspro.2016.09.019.

Lawrence TB, Hardy C, Phillips N (2012) Institutional effects of Interorganizational collaboration: the emergence of proto- institutions. Acad Manag J 45(1):281-290

Listiyarini T (2017) "CPO Mopoli Raya Dari Kawasan Legal," December 3. http://www.beritasatu.com/ekonomi/326984cpo-mopoli-raya-dari-kawasan-legal.html. Retrieved 2 Feb 2017

Menocal AR (2004) And if there was no state?: critical reflections on bates, Polanyi and Evans on the role of the state in promoting development. Third World Q 25(4):765-777. https://doi.org/10.1080/01436590410001678979

Michail N (2016) "IPOP disbands: a step backwards for sustainable palm oil in Indonesia?" Food Navigator, July 5. http:// www.foodnavigator.com/Market-Trends/IPOP-disbands-A-step-backwards-for-sustainable-palm-oil-in-Indonesia. Retrieved 12 Sept 2017

Milker J (2011) Sharing sovereignty for policy outcomes. Policy Soc 30:151-160 doi:http://dx.doi.org/10.1016/j.polsoc. 2011.07.007

Mol APJ (2010) Environmental authorities and biofuel controversies. Environ Polit 19(1):61-79. https://doi.org/10.1080/ 09644010903396085

Mügge D (2006) Private-public puzzles: inter-firm competition and transnational private regulation. New Polit Econ 11(2):177-200. https://doi.org/10.1080/13563460600655524

Nasiritousi N, Hjerpe M, Linnér BO (2016) The roles of non-state actors in climate change governance: understanding agency through governance profiles. Int Environ Agreements 16(1):109-126. https:/doi.org/10.1007/s10784-014-9243-8 
Nelson J (2017) Partnership for Sustainable Development: collective action by business, governments and civil society to achieve scale and transform markets. Business and Sustainable Development Commission, and Corporate Responsibility Initiative, Harvard Kennedy School, Cambridge, MA

Noy C (2008) Research sampling knowledge: the hermeneutics of snowball sampling in qualitative research. Int J Soc Res Methodol 11(4):327-344. https://doi.org/10.1080/13645570701401305.

Nurmayanti (2016) "6 Perusahaan Terancam Kena Denda KPPU." Liputan 6, May 2. http://bisnis.liputan6.com/read/ 2498444/6-perusahaan-terancam-kena-denda-kppu-rp-750-miliar. Retrieved 30 Nov 2017

Omont H (2005) "Roundtable on sustainable palm oil - RSPO: the second RSPO meeting in Jakarta in October 2004." Oilseeds and Fats Crops and. Lipids 12(2):125-128

Oosterveer, Peter. 2015. "Promoting Sustainable Palm Oil : Viewed from a Global Networks and Fl Ows Perspective." Journal of Cleaner Production 107. Elsevier Ltd: 146-53. doi:https://doi.org/10.1016/j.jclepro.2014.01.019.

Paoli GD, Yaap B, Wells PL, Sileuw A (2010) CSR, oil palm and the RSPO: translating boardroom philosophy into conservation action on the ground. Trop Conserv Sci 3(4):438-446. https://doi.org/10.1177/194008291000300408

Perez-batres, Luis A, Van V Miller, and Michael J Pisani. 2011. "Institutionalizing Sustainability: An Empirical Study of Corporate Registration and Commitment to the United Nations Global Compact Guidelines." Journal of Cleaner Production 19 (8). Elsevier Ltd: 843-51. doi:https://doi.org/10.1016/j.jclepro.2010.06.003.

Pesqueira L, Glasbergen P (2013) Playing the politics of scale: Oxfam's intervention in the roundtable on sustainable palm oil. Geoforum 45:296-304. https://doi.org/10.1016/j.geoforum.2012.11.017

Potts J, Lynch M, Wilkings A, Huppé G, Cunningham M, Voora V (2014) The state of sustainability initiatives review 2014. International Institute for Sustainable Development (IISD) and the International Institute for Environment and Development (IIED), London, England

Poynton S (2016) Failure of Indonesia's Palm Oil Commitment, not Bad News' [Commentary] Mongabay, July 27. https://news.mongabay.com/2016/07/failure-of-indonesias-ipop-not-bad-news-commentary/. Retrieved 2 Jan 2017

Pramudya EP, Hospes O, Termeer CJAM (2017a) Governing the palm oil sector through finance: the changing roles of the Indonesian state. Bull Indones Econ Stud 53(1):57-82. https://doi.org/10.1080/00074918.2016.1228829

Pramudya EP, Hospes O, Termeer CJAM (2017b) The disciplining of illegal palm oil plantations in Sumatra. Third World Q 1-21. doi:https://doi.org/10.1080/01436597.2017.1401462

Redaksi (2015a) "IPOP Tantang Kementan." Agroindonesia, December 15. http://agroindonesia.co.id/2015/12/ipoptantang-kementan/. Retrieved 7 Mar 2017

Redaksi (2015b) "Dirjen Perkebunan Terbitkan Surat Penundaan IPOP." Sawit Indonesia, December 18. https:// sawitindonesia.com/rubrikasi-majalah/berita-terbaru/dirjen-perkebunan-terbitkan-surat-penundaan-ipop/. Retrieved 12 Sept 2017

Rival A, Levang P (2014) Palms of Controversies CIFOR, Bogor

Rizkaprilisa W (2015) BKPM Minta IPOP Ciptakan Parameter Industri Minyak Sawit. Kabar 7, Agustus 25. https://kabar7. com/detail/ipop-diminta-ciptakan-parameter-industri-sawit-berkelanjutan-/5943/2015-08-25.

Robinson EH (2013) "The distinction between state and government" Geogr Compass 8:556-566. doi:https://doi.org/10. $1111 /$ gec3.12065

Rocha MIC (2008) Estado E Governo: Diferença Conceitual E Implicações Práticas N a Pós-Modernidade [state and government: conceptual difference and practical implications in Postmodernity]. Rev Uniara 21/22:140-145. https:// doi.org/10.25061/2527-2675/ReBraM/2007.v11i2.183

Rondinelli DA, Berry MA (2000) Citizenship in multinational corporations: social responsibility and sustainable development. Eur Manag J 18(1):70-84

RSPO. 2007. "Report on activities and progress of RSPO Indonesia liaison office (RILO)."

RSPO (2013) Principles and criteria for the production of sustainable palm oil 2013. RSPO Secretariat Sdn, Bhd

RSPO (2014) "Indonesian Vice-Minister of Trade and RSPO Open to Collaboration on Sustainable Palm Oil Stand." RSPO, June 6. http://www.rspo.org/news-and-events/news/indonesian-trade-viceminister-and-rspo-open-to-collaborationon-joint-sustainable-palm-oil-stand. Retrieved 30 Mar 2017

RSPO General assembly. 2015. The Statutes of the roundtable on sustainable palm oil.

RSPO. 2016. "RSPO Impact Report 2016."

RSPO (2017) RSPO Impact Update 2017. Impacts and Evaluation Division - RSPO Secretariat, Kuala Lumpur

RSPO Indonesia Liaison Office. 2008. "Summary of activities \& progress 2007-2008 (2 years)."

Salim T (2014) "Palm Oil Certification Gets Int'I Support." Jakarta Post, October 4. http://www.thejakartapost.com/news/ 2014/10/04/palm-oil-certification-gets-int-l-support.html. Retrieved 22 Mar 2017

Schouten, Greetje, and Pieter Glasbergen. 2011. "Creating Legitimacy in Global Private Governance : The Case of the Roundtable on Sustainable Palm Oil." Ecological Economics 70 (11). Elsevier B.V.: 1891-99. doi:https//doi.org/10.1016/j.ecolecon.2011.03.012

Schouten, Greetje, Pieter Leroy, and Pieter Glasbergen. 2012. "On the Deliberative Capacity of Private Multi-Stakeholder Governance : The Roundtables on Responsible Soy and Sustainable Palm Oil." Ecological Economics 83. Elsevier B.V.: 42-50. doi:https://doi.org/10.1016/j.ecolecon.2012.08.007.

Scott JC (1990) Domination and the arts of resistance: hidden transcripts, Yale University Press, New Haven

Scruton R (2007) The Palgrave Macmillan dictionary of political thought third edition. Palgrave Macmillan, Houndmills

Shah V (2016) "Indonesian palm oil pledge disbands." Eco-Business, July 1. http://www.eco-business.com/news/ indonesian-palm-oil-pledge-disbands/. Retrieved 12 Sept 2017

Smith, Timothy M., and Miriam Fischlein. 2010. "Rival Private Governance Networks: Competing to Define the Rules of Sustainability Performance." Global Environmental Change 20 (3). Elsevier Ltd: 511-22. doi:https:/doi.org/10.1016/j.gloenvcha.2010.03.006.

Subagyo (2013) "Kementan Berharap ISPO Jadi Syarat RSPO." Antara, May 10. https://www.antaranews.com/berita/ 374033/kementan-berharap-ispo-jadi-syarat-rspo. Retrieved 12 Sept 2017

Suharto, Rosediana. 2010. "Why Indonesia needs ISPO." Jakarta Post, December 2.

Suharto, Rosediana, Karim Husein, Sartono, Desi Kusumadewi, Asril Darussamin, Dhiny Nedyasari, Djaka Riksanto, et al. 2015. "Joint study on the similarities and differences of the ISPO and the RSPO certification systems."

Susila WR (2004) Contribution of oil palm industry to economic growth and poverty alleviation in Indonesia. J Litbang Pertanian 23(3):107-114 
Termeer CJAM (2009) Barriers to new modes of horizontal governance. Public Manag Rev 11(3):299-316. https://doi. org/10.1080/14719030902798180

UNDP (2015) "Indonesia Government Addresses Deforestation Challenges in Its Aim to Double Palm Oil Production by 2020." Press Release, March 11. http://www.undp.org/content/undp/en/home/presscenter/pressreleases/2015/03/ 11/indonesia-government-addresses-deforestation-challenges-in-its-aim-to-double-palm-oil-production-by-2020. html. Retrieved 12 Oct 2017

Varkkey H (2016) The haze problem in Southeast Asia: palm oil and patronage (Routledge Malaysian studies series). Routledge, Oxford

Vogel D (2010) The private regulation of global corporate conduct: achievements and limitations. Bus Soc 49(1):68-87. https://doi.org/10.1177/0007650309343407

von Geibler, Justus. 2013. "Market-Based Governance for Sustainability in Value Chains : Conditions for Successful Standard Setting in the Palm Oil Sector." Journal of Cleaner Production 56. Elsevier Ltd: 39-53. doi:https://doi.org/10. 1016/j.jclepro.2012.08.027.

Warburton E (2016) Jokowi and the new Developmentalism. Bull Indones Econ Stud 52(3):297-320. https://doi.org/10. 1080/00074918.2016.1249262

Weick KE (1987) Theorizing about Organizational Communication. In Jablin FM, Putnam LL, Roberts KH, Porter LW (eds) Handbook of Organizational Communication: An interdisciplinary perspective, Sage Publication, Newbury Park, pp 97-122

Weyzig F (2009) Political and economic arguments for corporate social responsibility: analysis and a proposition regarding the CSR agenda. J Bus Ethics 86:417-428. https://doi.org/10.1007/s10551-008-9855-4

Wijaya A, Glasbergen P (2016) Toward a new scenario in agricultural sustainability certification? The response of the Indonesian National Government to private certification. J Environ Dev 25(2):219-246. https://doi.org/10.1177/ 1070496516640857

Witoelar W (2016) "Turnaround in Palm Oil Industry?" Jakarta Post, October 24. http://www.thejakartapost.com/news/ 2015/10/24/turnaround-palm-oil-industry.html. Retrieved 11 Apr 2016

Submit your manuscript to a SpringerOpen ${ }^{\circ}$ journal and benefit from:

- Convenient online submission

- Rigorous peer review

Open access: articles freely available online

High visibility within the field

- Retaining the copyright to your article

Submit your next manuscript at $\gg$ springeropen.com 